\title{
Hubungan Pendampingan Suami dengan Kecemasan Ibu Bersalin Menghadapi Persalinan : Literature Review
}

\author{
Eka Rahayuning Tyas $^{1^{*}}$, Ratnawati ${ }^{2}$ \\ ${ }^{1,2}$ Program Studi Sarjan Keperawatan, Universitas Muhammadiyah Pekajangan Pekalongan, \\ Indonesia \\ *email : ekarahayuningtyas02@gmail.com
}

\begin{abstract}
Childbirth can be a source of psychological changes, such as anxiety. Anxiety can arise due to a lack of social support such as husband assistance. The presence of husband assistance is expected to reduse the anxiety experienced by the mother and the delivery process can run smoothly. This study aimed to determine the correlation between the husband's assistance and the mother's anxiety during childbirth. The research method used was the correlation method with literature review data collection. The searched articles were from 2011-2021. Those articles were searched through PubMed, Garba Garuda, and Google Scholar. The results were obtained in the form of full text and pdf, the reviewed using the JBI (Joanna Briggs Institute) instrument, extracted then discussed, and concluded. The results of the literature review of a 5 articles showed that most of the mothers in labor experienced moderate anxiety $53(34 \%)$ respondents. Most of the mothers who gave birth were accompanied by their husbands $110(55 \%)$ respondents. There was a correlation between the husband's assistance and the mother's anxiety. The $p$-value was ranged from $0,000-0,015(p<0,05)$. There is a relationship between the husband's presence and the mother's anxiety during childbirth.
\end{abstract}

Keywords : Childbirth; Anxiety during childbirth; Husband's presence

\begin{abstract}
Abstrak
Persalinan dapat menjadi sumber perubahan psikologis, seperti kecemasan. Rasa kecemasan dapat timbul karena kurangnya dukungan sosial seperti pendampingan suami. Adanya pendampingan suami diharap dapat mengurangi rasa kecemasan yang dialami ibu dan proses persalinan dapat berjalan dengan lancar. Penelitian ini bertujuan untuk mengetahui hubungan pendampingan suami dengan kecemasan ibu bersalin menghadapi persalinan : literature review. Metode penelitian menggunakan metode korelasi dengan pengumpulan data literature review. Pencarian artikel dari tahun 2011-2021 melalui penelusuran PubMed, Garba Garuda, dan Google Shcolar. Hasil pencarian yang didapatkan berupa fulltext dan pdf, kemudian direview dengan menggunakan instrument JBI (Joanna Briggs Institute), diekstraksi kemudian dibahas dan disimpulkan. Hasil penelitian literature review dari 5 artikel menunjukkan bahwa sebagian besar ibu bersalin mengalami kecemasan dalam tingkat sedang 53 (34\%), sebagian besar ibu bersalin didampingi suami sebanyak $110(55 \%)$, dan terdapat hubungan antara pendampingan suami dengan kecemasan ibu bersalin dengan nilai $p$-value $0,000-0,015(p<0,05)$. Ada hubungan pendampingan suami dengan kecemasan ibu bersalinmenghadapi persalinan.
\end{abstract}

Kata kunci : Ibu bersalin; Kecemasan persalinan; Pendampingan suami

\section{Pendahuluan}

Persalinan adalah sebuah proses pengeluaran hasil konsepsi (janin dan plasenta) dari dalam rahim menuju jalan lahir atau jalan lain [1]. Persalinan merupakan suatu kejadian yang normal dan akan dialami oleh ibu bersalin. Setiap proses persalinan berkemungkinan terjadinya potensi komplikasi yang akan mengancam nyawa, sehingga potensi tersebut perlu diperhatikan dengan ketat. Berdasarkan data Dinas 


\section{Prosiding Seminar Nasional Kesehatan Lembaga Penelitian dan Pengabdian Masyarakat Universitas Muhammadiyah Pekajangan Pekalongan}

Kesehatan Jawa Tengah jumlah kasus kematian ibu di Provinsi Jawa Tengah pada tahun 2018 sebanyak 421 kasus. Dengan demikian, angka kematian ibu di Jawa Tengah mencapai 88,05 per 100.000 kelahiran hidup dan sebesar $17,38 \%$ kematian ibu terjadi pada waktu persalinan [2].

Persalinan menjadi suatu pengalaman bagi ibu yang menantikan kelahiran bayinya dengan sehat dan proses persalinan yang berjalan lancar. Akan tetapi, saat persalinan akan ibu akan mengalami hambatan fisik penyebab rasa sakit bersalin seperti nyeri. Selain itu, ibu juga akan mengalami perubahan psikologi saat menghadapi persalinan dan perubahan tersebut adalah rasa kececemasan [1].

Berdasarkan penelitian yang dilakukan oleh Putri et al. [3] mengenai Hubungan Pendampingan Suami terhadap Tingkat Kecemasan Ibu selama Proses Persalinan Normal di Puskesmas Pagaden Subang didapatkan sebanyak 30 responden. Ibu bersalin yang tidak mengalami kecemasan sebanyak $2(6,7 \%)$ responden, cemas ringan sebanyak $5(16,7 \%)$ responden, cemas sedang sebanyak 19 (63,3\%) responden, dan cemas berat $14(13,3 \%)$ responden. Efek dari kecemasan yang berlebihan justru akan menghambat dan proses persalinan menjadi lebih lama serta kontraksi yang tidak adekuat [4].

Penyebab kecemasan ibu bersalin dapat dipengaruhi oleh adanya pendampingan suami selama proses persalinan. Pendampingan suami adalah seseorang yang berpatisipasi dan terlibat langsung dalam proses persalinan. Pendampingan suami dapat berpengaruh terhadap psikologi ibu. Dengan kehadiran orang terdekat akan memberikan rasa nyaman selama proses persalinan sehingga rasa cemas ibu dapat berkurang. Asuhan kasihan sayang yang diberikan suami saat mendampingi ibu dapat mempersingkat proses persalinan [5].

Pendampingan suami memiliki hubungan yang kuat selama proses persalinan. Kecemasan yang dialami ibu bersalin dapat berkurang sehingga dapat mempercepat proses persalinan dan menurunkan angka kematian ibu. Seorang suami yang menyaksikan langsung persalinan, akan memberikan kekuatan tersediri kepada sang ibu. Berdasarkan uraian di atas, peneliti tertarik untuk mengulas hubungan pendampingan suami dengan kecemasan ibu bersalin menghadapi persalinan menggunakan literature review.

\section{Metode}

Penelitian ini menggunakan metode korelasi dengan pengumpulan data literature review. Sumber database yang digunakan dalam penelitian ini yaitu PubMed, Garba Garuda, dan Google Scholar yang berupa artikel. Artikel yang digunakan dalam rentang waktu 10 tahun terakhir. Pencarian artikel menggunakan kata kunci Bahasa Indonesia "Ibu bersalin" , "Kecemasan persalinan", "Pendampingan suami" untuk pencarian Garba Garuda didapatkan 14 artikel dan Google Scholar didapatkan 11.300 artikel. Kemudian artikel diidentifikasi menggunakan judul didapatkan 14 artikel untuk Garba Garuda dan 10.400 artikel untuk Google Scholar. Artikel diidentifikasi lagi dengan menggunakan kriteria insklusi dan eksklusi sesuai topik didapatkan 2 artikel untuk Garba Garuda dan 2 artikel untuk Google Scholar. Pada pencarian artikel Bahasa Inggris di PubMed menggunakan kata kunci "Childbirth" , "Anxiety during childbirth", "Husband's presence" didapatkan 18 artikel. Kemudian diidentifikasi berdasarkan judul 


\section{Prosiding Seminar Nasional Kesehatan Lembaga Penelitian dan Pengabdian Masyarakat Universitas Muhammadiyah Pekajangan Pekalongan

didapatkan 16 artikel. Sesuai dengan kriteria insklusi dan eksklusi didapatkan 1 artikel. Artikel yang didapatkan dalam Bahasa Indonesia maupun Bahasa Inggris, berupa original artikel dan instrument kecemasan menggunkan HARS (Hamilton Anxiety Rating Scale) dan STAI (State-Trait Anxiety Investory)sehingga didapatkan 5 artikel dalam bentuk fullext dan format Pdf.

\section{Hasil dan Pembahasan}

\section{Hasil}

Berdasarkan dari hasil analisis data artikel yang direview dari pendampingan suami didapatkan 200 responden dari lima artikel penelitian. Hasil analisa tersebut dapat dilihat pada tabel sebagai berikut.

Tabel 1. Hasil Analisis Pendampingan Suami

\begin{tabular}{|c|c|c|c|c|c|c|}
\hline \multirow{3}{*}{ No } & \multicolumn{2}{|l|}{ Artikel } & \multicolumn{4}{|c|}{ Pendampingan Suami } \\
\hline & \multirow{2}{*}{ Penulis } & \multirow{2}{*}{ Tahun } & \multicolumn{2}{|c|}{ Didampingi } & \multicolumn{2}{|c|}{ Tidak didampingi } \\
\hline & & & $\mathrm{F}$ & $\%$ & $\mathrm{~F}$ & $\%$ \\
\hline 1 & Eka Kusfarini \& Nur Saidah & 2012 & 11 & 45,8 & 13 & 54,2 \\
\hline 2 & Fitriani, dkk & 2020 & 27 & 90 & 3 & 10 \\
\hline 3 & Dwi Diana Putri, dkk & 2020 & 14 & 46,7 & 16 & 53,3 \\
\hline 4 & Rilyani & 2017 & 30 & 50 & 30 & 50 \\
\hline 5 & Atefeh Salehi, dkk & 2016 & 28 & 50 & 28 & 50 \\
\hline \multicolumn{3}{|c|}{ Total masing-masing pendampingan suami } & 110 & 55 & 90 & 45 \\
\hline
\end{tabular}

Hasil analisa menunjukkan bahwa sebagian besar responden memiliki pendampingan suami sebanyak 110 (55\%).

Berdasarkan hasil analisis artikel yang direview dari kecemasan ibu bersalin menggunakan alat ukur HARS (Hamilton Anxiety Rating Scale) didapatkan 154 responden dari penelitian : [6], [7], [3], dan [8]. Hasil analisa tersebut dapat dilihat pada tabel sebagai berikut.

Tabel 2. Hasil Analisis Kecemasan Ibu Bersalin dengan HARS

\begin{tabular}{|c|c|c|c|c|c|c|c|c|c|c|}
\hline \multirow{3}{*}{ No } & \multicolumn{2}{|l|}{ Artikel } & \multicolumn{8}{|c|}{ Tingkat Kecemasan. } \\
\hline & \multirow{2}{*}{ Penulis } & \multirow{2}{*}{ Tahun } & \multicolumn{2}{|c|}{$\begin{array}{l}\text { Tidak } \\
\text { cemas. }\end{array}$} & \multicolumn{2}{|c|}{$\begin{array}{l}\text { Cemas } \\
\text { ringan }\end{array}$} & \multicolumn{2}{|c|}{$\begin{array}{l}\text { Cemas } \\
\text { sedang }\end{array}$} & \multicolumn{2}{|c|}{$\begin{array}{l}\text { Cemas } \\
\text { berat. }\end{array}$} \\
\hline & & & $\mathrm{F}$ & $\%$ & $\mathrm{~F}$ & $\%$ & $\mathrm{~F}$ & $\%$ & $\mathrm{~F}$ & $\%$ \\
\hline 1 & $\begin{array}{l}\text { Eka Kusfarini \&Nur } \\
\text { Saidab. }\end{array}$ & 2012 & 3 & 12,5 & 5 & 20 & 10 & 41,7 & 6 & 25,0 \\
\hline 2 & Fitriani, dkk & 2020 & 0 & 0 & 22 & 73,3 & 5 & 16,7 & 3 & 10 \\
\hline 3 & Dwi Diana Putri, dkk & 2020 & 2 & 6,7 & 5 & 16,7 & 19 & 63,3 & 14 & 13,3 \\
\hline 4 & Rilvani & 2017 & 11 & 18,3 & 11 & 18,3 & 19 & 31,7 & 19 & 31,7 \\
\hline \multicolumn{3}{|c|}{ Total masing-masing kecemasan } & 16 & 11 & 43 & 28 & 53 & 34 & 42 & 27 \\
\hline \multicolumn{3}{|c|}{ Total responden } & \multicolumn{8}{|c|}{154} \\
\hline
\end{tabular}

Hasil analisa menunjukkan bahwa sebagian besar responden ibu bersalin mengalami kecemasan sedang sebanyak 53 (34,4\%).

Berdasarkan dari hasil analisis artikel yang direview dari kecemasan ibu bersalin menggunakan alat ukur STAI (State-Trait Anxiety Investory) didapatkan 56 responden dari penelitian : [9]. Hasil analisa tersebut dapat dilihat pada tabel sebagai berikut. 


\section{Prosiding Seminar Nasional Kesehatan 2021 Lembaga Penelitian dan Pengabdian Masyarakat Universitas Muhammadiyah Pekajangan Pekalongan}

Tabel 3. Hasil Analisis Kecemasan Ibu Bersalin dengan STAI

\begin{tabular}{|c|c|c|c|c|c|c|}
\hline \multirow{3}{*}{ No } & \multicolumn{2}{|l|}{ Artikel } & \multicolumn{4}{|c|}{ Skor kecemasan } \\
\hline & \multirow{2}{*}{ Penulis } & \multirow{2}{*}{ Tahun } & \multicolumn{2}{|c|}{ Didampingi } & \multicolumn{2}{|c|}{ Tidak didampingi } \\
\hline & & & Rata-rata & SD & Rata-rata & SD \\
\hline 1 & Atefeh Salehi, dkk & 2016 & 36 & 10,7 & 59,1 & 12,02 \\
\hline \multicolumn{3}{|c|}{ Total responden } & \multicolumn{4}{|c|}{56} \\
\hline
\end{tabular}

Hasil analisa menunjukkan bahwa rata-rata skor kecemasan responden yang tidak didampingi suami lebih tinggi dari pada yang didampingi yaitu 59,1 dengan standar deviasi 12,02 .

Berdasarkann dari hasil analisis artikel yang direview, dari penelitian : [6], [7], [3], [8], dan [9] pada tabel 4 menunjukkan bahwa sebagian besar terdapat hubungan pendampingan suami dengan kecemasan ibu bersalin menghadapi persalinan dengan nilai $p$-value 0,000-0,015 $(p<0,05)$. Hasil analisa tersebut dapat dilihat pada tabel sebagai berikut.

Tabel 4. Hasil Analisis Hubungan Pendampingan Suami dengan Kecemasan Ibu Bersalin Menghadapi Persalinan

\begin{tabular}{|c|c|c|c|c|}
\hline No & Artikel & & $\mathrm{p}-$ & Keteranaan \\
\hline TNO & Penulis & Tahun & value & Keterdingdn \\
\hline 1 & $\begin{array}{l}\text { Eka Kusfarini \& } \\
\text { Nur Saidah }\end{array}$ & 2012 & 0,015 & $\begin{array}{l}\text { Ada hubungan pendampingan suami dengan kecemasan } \\
\text { ibu bersalin menghadapi persalinan }\end{array}$ \\
\hline 2 & Fitriani, dkk & 2020 & 0,003 & $\begin{array}{l}\text { Ada hubungan pendampingan suami dengan kecemasan } \\
\text { ibu bersalin menghadapi persalinan }\end{array}$ \\
\hline 3 & $\begin{array}{l}\text { Dwi Diana Putri, } \\
\text { dkk }\end{array}$ & 2020 & 0,007 & $\begin{array}{l}\text { Ada hubungan pendampingan suami dengan kecemasan } \\
\text { ibu bersalin menghadapi persalinan }\end{array}$ \\
\hline 4 & Rilyani & 2017 & 0,000 & $\begin{array}{l}\text { Ada hubungan pendampingan suami dengan kecemasan } \\
\text { ibu bersalin menghadapi persalinan }\end{array}$ \\
\hline 5 & Atefeh Salehi, dkk & 2016 & 0,001 & $\begin{array}{l}\text { Ada hubungan pendampingan suami dengan kecemasan } \\
\text { ibu bersalin menghadapi persalinan }\end{array}$ \\
\hline \multicolumn{4}{|c|}{ Total $p<0,05$} & $\begin{array}{l}\text { Ada hubungan pendampingan suami dengan kecemasan } \\
\text { ibu bersalin menghadapi persalinan }\end{array}$ \\
\hline
\end{tabular}

\section{Pembahasan}

Kehadiran pendamping persalinan dapat memberikan dorongan bagi ibu untuk mengurangi kecemasan khususnya pendampingan dari seorang suami. Kehadiran suami dapat memberi ketenangan dan menjauhkan istri dari rasa cemas yang akhirnya dapat mempersulit proses persalinan, kehadiran suami berpengaruh positif secara psikologis, dan berdampak positif juga pada kesiapan ibu secara fisik pada saat bersalin [10].

Berdasarkan hasil penelitian yang diperoleh menunjukkan adanya pendampingan suami sebanyak 110 (55\%) responden. Pendampingan suami sangat berpengaruh terhadap psikologi ibu. Dengan hadirnya suami akan memberikan rasa nyaman saat proses persalinan sehingga kecemasan ibu pun akan berkurang. Suami dianjurkan 


\section{Prosiding Seminar Nasional Kesehatan 2021 Lembaga Penelitian dan Pengabdian Masyarakat Universitas Muhammadiyah Pekajangan Pekalongan}

untuk melakukan peran aktif dalam mendukung ibu dan mengidentifikasi langkahlangkah yang mungkin untuk kenyamanan ibu [5].

Penelitian ini sejalan dengan penelitian Wulan et al. [10]yang menunjukkan hasil adanya pendampingan suami yaitu (60\%), suami merupakan anggota keluarga terdekat ibu dan lebih mengetahui kebutuhan ibu, seperti dukungan emosional dan fisik pada saat proses persalinan. Penelitian ini juga sejalan dengan penelitian yang dilakukan oleh Hasanah [11]diperoleh hasil adanya pendampingan suami yaitu $(90 \%)$ bahwa hasil penelitian tersebut menunjukkan adanya pendampingan suami yang diberikan terhadap ibu saat menghadapi persalinan tentunya akan memberi kontribusi yang baik, seperti rasa tenang dan nyaman sehingga dapat mengurangi tingkat kecemasan pada ibu.

Berdasarkan hasil literature review artikel dengan menggunakan alat ukur kecemasan HARS (Hamilton Rating Scale for Anxiety) menunjukan bahwa sebagian besar responden memiliki tingkat kecemasan sedang yaitu 53 (34\%). Penelitian ini sejalan dengan penelitian yang dilakukan oleh Anggaresi [12]diperoleh hasil sebagian besar responden mengalami kecemasan sedang sebanyak 18 (60,7\%) dengan nilai pvalue 0,038 $(\mathrm{p}<0,05)$. Sedangkan menggunakan alat ukur kecemasan STAI (StateTrait Anxiety Investory) didapatkan hasil rata-rata skor kecemasan dengan pendampingan yaitu 36 standar deviasi 10,1 dan tanpa pendampingan 59,1 standar deviasi 12,02. Kecemasan sedang dapat membuat seseorang untuk memusatkan perhatian pada hal penting dan mengesampingkan yang lain, sehingga seseorang mengalami perhatian yang selektif, tetapi dapat melakukan sesuatu yang lebih terarah [13]. Ibu yang mengalami cemas akan merasakan ketakutan terhadap kelancaran persalinannya, rasa takut ini menyebabkan pembuluh-pembuluh arteri yang menuju rahim berkontraksi dan menegang sehingga menimbulkan rasa tidak nyaman bagi ibu bersalin. Selain itu, ibu yang mengalami cemas berlebihan akan membuat ibu merasa lebih lelah dan tenaga yang dibutuhkan saat persalinan akan berkurang [5]. Berdasarkan penelitian Kartikasari et al. [14]bahwa kecemasan timbul dapat diakibatkan oleh karena rasa senang terhadap bayi yang akan dilahirkan dan rasa nyeri yang sedang dirasakan. Apabila kondisi cemas yang tidak stabil dibawa terus menerus pada proses persalinan, dapat menyebabkan proses persalinan tidak lancar.Menurut Indrayani dan Djami[4] usia dan pendidikan ibu bersalin dapat memengaruhi kecemasan yang dialami. Ibu yang memiliki tingkat pendidikan tinggi maka pengetahuan mengenai persiapan persalinan yang didapat ibu lebih luas daripada ibu yang memiliki pendidikan yang kurang. Semakin bertambah usia ibu, maka akan semakin konstruktif dalam menggunakan koping terhadap masalah kecemasan yang sedang dihadapi.

Hasil analisis artikel yang di review menunjukkan antara hubungan kedua variable yaitu varibel pendampingan suami dan kecemasan menghadapi persalinan, didapatkan hasil bahwa terdapat hubungan pendampingan suami dengan kecemasan menghadapi persalinan pada ibu bersalin dengan nilai $p$-value $0,000-0,015(p<0,05)$. Penelitian ini sejalan dengan penelitian yang dilakukan oleh Rosdiana [15]dengan hasil penelitian didapatkan nilai $p$-value $0,030(p<0,05)$ hasil analisis tersebut menunjukkan adanya 


\section{Prosiding Seminar Nasional Kesehatan 2021 Lembaga Penelitian dan Pengabdian Masyarakat Universitas Muhammadiyah Pekajangan Pekalongan}

hubungan pendampingan suami dengan kecemasan ibu bersalin menghadapi persalinan.

Penelitian ini juga sejalan dengan penelitian yang dilakukan oleh Primasnia et al.[16]didapatkan hasil $p$-value $0,007(p<0,05)$ yang artinya terdapat hubungan yang signifikan antara pendampingan suami dengan kecemasan ibu bersalin menghadapi persalinan. Pada penelitian yang dilakukan oleh Sabariah [17]menunjukkan hasil pvalue $0,021 \quad(p<0,05)$ yang artinya juga terdapat hubungan pendampingan suami dengan kecemasan ibu bersalin menghadapi persalinan. Menurut Wijaya et al.[18]bahwa kehadiran suami mempunyai arti yang besar karena dapat berbuat banyak untuk membantu ibu saat persalinan. Manfaat pendampingan suami tersebut akan memberi dorongan pada ibu selama persalinan, membatu menciptakan suasana nyaman dalam ruang bersalin, dan membatu mengatasi rasa tidak nyaman ibu yaitu salah satunya adalah rasa kecemasan.

Partisipasi suami yang cukup tinggi dalam pendampingan istri menunjukkan bahwa suami menyadari akan peran yang bisa dilakukannya dalam memberikan dukungan fisik dan dorongan moral kepada istri yang sedang melahirkan. Peran tersebut seperti mendengarkan keluhan ibu, memijat punggung ibu, memberikan ibu minum atau makan yang dapat mengurangi rasa kecemasan yang dialami ibu sehingga dengan adanya pendampingan suami proses persalinan berjalan dengan lancar [19].

Berdasarkan penelitian yang dilakukan oleh Nikmah[20]mengungkapkan bahwa rasa sayang dan simpati yang diberikan oleh suami akan memberikan kekuatan tersendiri yang dapat memicu semangat ibu untuk lebih kuat dalam melalui proses persalinan. Kehadiran suami akan membawa ketenangan dan menjauhkan ibu dari kecemasan yang dapat mempersulit proses kelahiran dan persalinan. Kehadiran suami akan membawa pengaruh positif secara psikologis, dan berdampak positif pula pada kesiapan ibu secara fisik sehingga dapat mempermudah proses persalinan.

\section{Kesimpulan}

Pada penelitian ini dapat disimpulkan bahwa sebagian besar ibu bersalin memiliki pendampingan suami sebanyak 110 (55\%).Kecemasan yang dimiliki ibu bersalin sebagian besar dalam tingkat kecemasan sedang sebanyak 53 (34,4\%).Terdapat hubungan pendampingan suami dengan kecemasan ibu bersalin menghadapi persalinan dengan $p$-value 0,000-0,015 $(p<0,05)$.

\section{Referensi}

[1] S. Diana, E. Mail, and Z. Rufaida, Buku Ajar Asuhan Kebidanan Persalinan dan Bayi Baru Lahir. Surakarta: Surakarta: CV Oase Grup, 2019.

[2] Dinkes, Profil Kesehatan Jawa tengah. Jawa Tengah: Dinas Kesehatan Provinsi Jawa Tengah, 2018.

[3] D. D. Putri, A. Nuraeni, and Y. Suryati, "Hubungan Kecemasan Ibu Selama Proses Persalinan Normal di Puskesmas Pagaden Subang," J. IIm. IImu dan Teknol. Rekayasa, vol. 3, no. 2, pp. 53-59, 2020, doi: 10.31962/jitr.v3i2.99.

[4] Indrayani and M. E. U. Djami, Update Asuhan Persalinan dan Bayi Baru Lahir, 1st ed. Jakarta: Jakarta: Trans Info Media, 2016. 


\section{Prosiding Seminar Nasional Kesehatan Lembaga Penelitian dan Pengabdian Masyarakat Universitas Muhammadiyah Pekajangan Pekalongan}

[5] Padila, Keperawatan Maternitas. Yogyakarta: Yogyakarta : Nuha Medika, 2017.

[6] E. Kusfarini and N. Saidah, "Pendampingan Suami dengan Tingkat Kecemasan Ibu saat Menghadapi Proses Persalinan di BPS Ny. H. Amalia, Amd.Keb Simogirang Prambon Sidoarjo," J. IIm. Kesehat. Politek. Kesehat. Majapahit Mojokerto, vol. 4, no. 1, pp. 22-35, 2012.

[7] Fitriani, N. Darwis, and E. Wardanengsih, "Hubungan Pendampingan Suami terhadap Tingkat Kecemasan Ibu selama Proses Persalinan di Rumah Sakit dr. M. Yasin Bone," Jounal Heal. Nurs. Midwifery Sci. Adpertisi, vol. 1, no. 2, pp. 42-56, 2020.

[8] Rilyani, "Hubungan Pendampingan Suami dengan Tingkat Kecemasan Ibu Bersalin (Kala I) di Ruang Bersalin Rumah Sakit Pertamina Bintang Amin," J. Kesehat. Holistik, vol. 11, no. 3, pp. 188-195, 2017.

[9] A. Salehi, F. Fahami, and M. Beigi, "The Effect of Presence of Trained Husbands beside Their Wives during Childbirth on Women's Anxiety," Iran. J. Nurs. Midwifery Res., vol. 21, no. 6, pp. 611-615, 2016, doi: 10.4103/17359066.197672.

[10] S. Wulan, K. Sitepu, R. Gurusinga, and H. Barus, "Hubungan Pendamping Persalinan dengan Kecemasan Ibu Bersalin di Klinik Kasih Ibu Kecamatan Galang Kabupaten Deli Serdang," vol. 2, no. 2, 2020.

[11] M. Hasanah, "Pengaruh Pendampingan Suami terhadap Pengurangan Rasa Cemas pada Proses Persalinan Ibu Primigravida Kala I di Klinik Pratama Jannah Medan Tembung," 2018.

[12] N. Anggaresi, "Hubungan pendampingan suami dengan tingkat kecemasan ibu menghadapi persalinan di rsu yarsi pontianak," vol. 3, no. 2, pp. 97-106, 2018.

[13] Sutejo, Keperawatan Jiwa. Yogyakarta : Pustaka Baru Press, 2019.

[14] E. Kartikasari, Hernawily, and A. Halim, "Hubungan Pendampingan Keluarga dengan Tingkat Kecemasan Ibu Primigravida dalam Menghadapi Proses Persalinan," J. Keperawatan ISSN 1907-0357, vol. XI, no. 2, pp. 250-257, 2015.

[15] M. Rosdiana, "Hubungan Pendampingan Suami terhadap Tingkat Kecemasan Ibu Bersalin di RB Citra Palembang," J. Kesehat. dan Pembang., vol. 9, no. 17, pp. 54-60, 2019.

[16] P. Primasnia, Wagiyo, and Elisa, "Hubungan Pendampingan Suami Dengan Tingkat Kecemasan Ibu Primigravida Dalam Menghadapi Proses Persalinan Kala I Di Rumah Bersalin Wilayah Kota Ungaran," J. Ilmu Keperawatan dan Kebidanan, vol. 1, no. 4, pp. 212-216, 2013, [Online]. Available: http://pmb.stikestelogorejo.ac.id/ejournal/index.php/ilmukeperawatan/article/view/184.

[17] P. Y. Sabariah, "Hubungan Pendampingan Suami dalam Persalinan dengan Tingkat Kecemasan pada Ibu Bersalin di PMB Siswati, SST Kota Tanjung Pinang," J. Cakrawala Kesehat., vol. X, no. 02, pp. 142-150, 2019.

[18] D. E. Wijaya, Rillyani, R. Wandini, and A. Wardiyah, "Pengaruh Pendampingan Suami terhadap Lamanya persalinan Kala II di Ruang Delima RSUD DR.H.Abdul Moelek Lampung," J. Keperawatan, vol. 6 (1), pp. 6-14, 2015. 


\section{Prosiding Seminar Nasional Kesehatan Lembaga Penelitian dan Pengabdian Masyarakat Universitas Muhammadiyah Pekajangan Pekalongan

[19] D. E. A. Sari, N. I. Sari, and N. P. Zulaikha, "Hubungan Pendampingan Suami dalam Persalinan dengan Kemajuan Persalinan Kala I Fase Aktif di RB. Bunda Puja Tembilahan," J. Selodang Mayang, vol. 6, no. 1, pp. 31-38, 2018.

[20] K. Nikmah, "Hubungan Pendampingan Suami dengan Tingkat Kecemasan Ibu Primi Gravidarum saat Menghadapi Persalinan," J. Qual. Women's Heal., vol. 1, no. 2, pp. 15-21, 2018, doi: 10.30994/jqwh.v1i2.12. 